Research Article

\title{
Synthesis of Ca-Doped Three-Dimensionally Ordered Macroporous Catalysts for Transesterification
}

\author{
Tanat Chokpanyarat, ${ }^{1}$ Vittaya Punsuvon (D), ${ }^{1,2}$ and Supakit Achiwawanich (D) \\ ${ }^{1}$ Department of Chemistry, Faculty of Science, Kasetsart University, Bangkok, Thailand \\ ${ }^{2}$ Center of Excellence-Oil Palm, Faculty of Science, Kasetsart University, Bangkok, Thailand \\ Correspondence should be addressed to Supakit Achiwawanich; fsciska@ku.ac.th
}

Received 27 October 2017; Revised 27 December 2017; Accepted 8 January 2018; Published 13 March 2018

Academic Editor: Joon-Hyung Lee

Copyright @ 2018 Tanat Chokpanyarat et al. This is an open access article distributed under the Creative Commons Attribution License, which permits unrestricted use, distribution, and reproduction in any medium, provided the original work is properly cited.

The novel three-dimensionally ordered macroporous (3DOM) $\mathrm{CaO} / \mathrm{SiO}_{2}, 3 \mathrm{DOM} \mathrm{CaO} / \mathrm{Al}_{2} \mathrm{O}_{3}$, and $3 \mathrm{DOM}^{\mathrm{Ca}} \mathrm{Al}_{12} \mathrm{Al}_{14} \mathrm{O}_{32} \mathrm{Cl}_{2}$ catalysts for biodiesel transesterification were prepared by sol-gel method. The 3DOM catalysts were characterized by scanning electron microscopy (SEM), X-ray diffraction (XRD), and Fourier transform infrared spectroscopy (FTIR). The hierarchical porous structure was achieved; however, only $3 \mathrm{DOM} \mathrm{CaO} / \mathrm{Al}_{2} \mathrm{O}_{3}$ and $3 \mathrm{DOM} \mathrm{Ca} \mathrm{Ca}_{12} \mathrm{Al}_{14} \mathrm{O}_{32} \mathrm{Cl}_{2}$ catalysts were used for transesterification due to high amount of active $\mathrm{CaO}$. Various parameters such as methanol to oil molar ratio, catalyst concentration, reaction time, and their influence on the biodiesel production were studied. The result showed that $99.0 \%$ RPO conversion was achieved using the $3 \mathrm{DOM} \mathrm{Ca}{ }_{12} \mathrm{Al}_{14} \mathrm{O}_{33} \mathrm{Cl}_{2}$ as a catalyst under the optimal condition of $12: 1$ methanol to oil molar ratio and 6 wt.\% catalyst with reaction time of 3 hours at $65^{\circ} \mathrm{C}$.

\section{Introduction}

In recent years, the demand of fossil energy is increasing by a rapid growth of global transportation and industrial evolution, thus driving world economic. In addition, the fossil energy becomes expensive due to limited resources. It is predicted that the fossil energy would be exhausted by 20 centuries [1]. Hence, more researchers are focusing on new alternative energy resources. Biodiesel is one of the alternative energies consisting of monoalkyl ester that was derived from recycled cooking oil, vegetable oil, and animal fats. In addition, it is renewable, clean-combustion diesel replacement. Biodiesel is produced by transesterification from either vegetable oil or animal fat with methanol in the presence of a catalyst, resulting in glycerol and biodiesel. This clean diesel provides low carbon monoxide emission, low greenhouse gases emission, noncombustion of hydrocarbon, and nonsulfur dioxide content compared to those of fossil fuel. The physical properties and energy content of biodiesel are similar to fossil fuel; therefore, it can be used to function conventional diesel engines efficiently without modification [2].
The catalysts for transesterification are categorized into two groups: homogeneous and heterogeneous. The homogeneous catalysts such as sodium hydroxide or potassium hydroxide are most often used commercially because of their high catalytic activity and high productivity. However, the product must be neutralized, preventing corrosion in engine. The solid catalysts or heterogeneous catalysts, on the other hand, are easily separated from the produced biodiesel. For example, $\mathrm{KNO}_{3} / \mathrm{Al}_{2} \mathrm{O}_{3}$, $\mathrm{La}_{2} \mathrm{O}_{3} / \mathrm{ZrO}_{2}$, and $\mathrm{K}_{2} \mathrm{CO}_{3}$ on alumina/silica support are highly active for transesterification of vegetable oils [3-5].

Recently, a new hierarchical material named threedimensionally ordered macroporous (3DOM) has been extensively studied because of its unique ordered structure with the interconnected wall. Owning to this structure, the refined palm oil (RPO) may not only enter the 3DOM catalyst pores easily but also transfer into the inner area of the catalyst. This may enhance biodiesel production. In this work, the threedimensionally ordered macroporous (3DOM) $\mathrm{CaO} / \mathrm{SiO}_{2}$, $3 \mathrm{DOM} \mathrm{CaO} / \mathrm{Al}_{2} \mathrm{O}_{3}$, and $3 \mathrm{DOM} \mathrm{Ca}_{12} \mathrm{Al}_{14} \mathrm{O}_{32} \mathrm{Cl}_{2}$ were synthesized by the sol-gel method (SG). The obtained 3DOM catalysts were characterized by various techniques such as X-ray diffraction (XRD), scanning electron microscopy 
(SEM), and Fourier transform infrared spectroscopy (FTIR). The catalytic efficiency of the 3DOM catalysts for transesterification was investigated. Optimal conditions for transesterification using the obtained 3DOM catalysts were studied. The property of the produced biodiesel using the 3DOM catalysts was reported herein.

\section{Experimental Procedures}

2.1. Synthesis of PMMA Colloidal Crystal. The monodispersed poly(methyl methacrylate) (PMMA) spheres were synthesized by emulsifier-free emulsion polymerization as previously described by Phumthiean [6]. A mixture of water and methyl methacrylate was stirred at $75^{\circ} \mathrm{C}$ under nitrogen $\left(\mathrm{N}_{2}\right)$ atmosphere. Then, $1.2 \mathrm{~g}$ of $2,2^{\prime}$-azobis(2-amidinopropane) dihydrochloride, an initiator, was added into the mixture and stirred for $2 \mathrm{~h}$ until reaction was completed. After reaction, the mixture was cooled down to room temperature and filtrated through glass wool to remove large particles. The PMMA spheres were self-assembled by gravitation until a clear solution and a colloidal crystal arrays were observed. The obtained PMMA arrays were dried at $60^{\circ} \mathrm{C}$ for $24 \mathrm{~h}$.

\subsection{Preparation of 3DOM Catalysts by Sol-Gel Method. The} Ca-doped 3DOM catalysts were synthesized by the sol-gel method using calcium nitrate tetrahydrate $\left(\mathrm{Ca}\left(\mathrm{NO}_{3}\right)_{2} \cdot 4 \mathrm{H}_{2} \mathrm{O}\right)$ and tetraethoxysilane (TEOS) for $3 \mathrm{DOM} \mathrm{Cao} / \mathrm{SiO}_{2}$, calcium nitrate tetrahydrate $\left(\mathrm{Ca}\left(\mathrm{NO}_{3}\right)_{2} \cdot 4 \mathrm{H}_{2} \mathrm{O}\right)$ and aluminium nitrate nonahydrate $\left(\mathrm{Al}\left(\mathrm{NO}_{3}\right)_{3} \cdot 9 \mathrm{H}_{2} \mathrm{O}\right)$ for $3 \mathrm{DOM} \mathrm{CaO} / \mathrm{Al}_{2} \mathrm{O}_{3}$, and aluminium isopropoxide (AIP) and calcium chloride dihydrate $\left(\mathrm{CaCl}_{2} \cdot 2 \mathrm{H}_{2} \mathrm{O}\right)$ for $3 \mathrm{DOM} \mathrm{Ca}_{12} \mathrm{Al}_{14} \mathrm{O}_{32} \mathrm{Cl}_{2}$. The precursor of each catalyst was mixed in ethanol and was stirred for $30 \mathrm{~min}$ at room temperature. Subsequently, each precursor solution was added on the PMMA arrays until the PMMA template was saturated with the precursor solution. The materials were dried at $80^{\circ} \mathrm{C}$ for $24 \mathrm{~h}$ and calcined at 700 and $800^{\circ} \mathrm{C}$. The heating rate was set at $2^{\circ} \mathrm{C} / \mathrm{min}$. The atomic mol percentage is shown in Table 1.

2.3. Characterization of the 3DOM Catalysts. All 3DOM catalysts were characterized by XRD, FTIR, and SEM techniques in order to investigate the crystal structure, functional group, and morphology of the synthesized materials, respectively. X-ray diffraction measurements were performed by a Bruker D8 advance diffractometer using $\mathrm{Cu} \mathrm{K} \alpha$ radiation $(\lambda=0.154 \mathrm{~nm})$ with current of $40 \mathrm{~mA}$ and voltage of $40 \mathrm{kV}$. Data were collected in range of $10-70^{\circ} 2 \theta$ with step size of $0.02^{\circ}$.

The infrared spectra were recorded at room temperature in the range of $400-4000 \mathrm{~cm}^{-1}$ with 32 scans and $4 \mathrm{~cm}^{-1}$ resolution using a Bruker Equinox 55 FTIR spectrometer. The surface morphology of the catalysts was observed by a FEI Quanta 450 scanning electron microscope (SEM) using an acceleration voltage of $20 \mathrm{kV}$.

2.4. Transesterification: Catalytic Study of the Synthesized 3DOM Catalysts. The transesterification condition, adapted from Suwanthai [7], was employed to study catalytic efficiency
TABle 1: Atomic mol percentage used for Ca-doped 3DOM material synthesis.

\begin{tabular}{lc}
\hline Material & Atomic mol percentage \\
\hline 3DOM CaO$/ \mathrm{SiO}_{2}$ & $2: 1(\mathrm{~mol} \mathrm{Ca}: \mathrm{mol} \mathrm{Si})$ \\
$3 \mathrm{DOM} \mathrm{CaO} / \mathrm{Al}_{2} \mathrm{O}_{3}$ & $2: 1(\mathrm{~mol} \mathrm{Ca}: \mathrm{mol} \mathrm{Al})$ \\
3DOM Ca & $2: 1(\mathrm{~mol} \mathrm{Ca}: \mathrm{mol} \mathrm{Al})$ \\
\hline
\end{tabular}

of two Ca-doped 3DOM materials, 3DOM $\mathrm{CaO} / \mathrm{Al}_{2} \mathrm{O}_{3}$ and $3 \mathrm{DOM} \mathrm{Ca}_{12} \mathrm{Al}_{14} \mathrm{O}_{32} \mathrm{Cl}_{2}$. The reaction was carried out in a $100 \mathrm{~mL}$ three-neck round-bottom flask equipped with a magnetic stirrer. A $10 \mathrm{~g}$ of palm oil was added into the flask, and then the temperature of oil was raised to the designated temperature. The 3DOM catalyst and methanol were added into the flask using $8 \mathrm{wt} . \%$ of catalyst amount and 12:1 of molar ratio of methanol to oil. The reaction was then stirred under $750 \mathrm{rpm}$ at the temperature of $65^{\circ} \mathrm{C}$ for $3 \mathrm{~h}$. After the reaction was completed, the $3 \mathrm{DOM}$ catalyst was separated by centrifugation.

An optimal condition for transesterification using the $3 \mathrm{DOM}$ catalyst was achieved by varying the amount of the 3DOM catalyst (6-12 wt.\%), molar ratio of methanol to oil $(9: 1-24: 1)$, and reaction time $(3-5 h)$, respectively. The reaction temperature was fixed at $65^{\circ} \mathrm{C}$.

2.5. Refined Palm Oil (RPO) Conversion Analysis and Biodiesel Analysis. Nuclear magnetic resonance (NMR) spectra were recorded on a VARIAN NMR spectrometer. The spectrum was obtained at $400 \mathrm{MHz}$ for ${ }^{1} \mathrm{H}$, using $\mathrm{CDCl}_{3}$ as a solvent. The conversion of fatty acid methyl ester was measured using peak areas of the ${ }^{1} \mathrm{H}$ NMR signals from methyl ester at $3.6 \mathrm{ppm}$ and that of glycerol at $2.3 \mathrm{ppm}$ [8]. The percentage of the fatty acid methyl ester conversion was calculated as follows:

$$
C=\left(\frac{2 A_{1}}{3 A_{2}}\right) \times 100,
$$

where $C$ is the percentage of fatty acid methyl ester conversion, $A_{1}$ is peak of the methyl esters, and $A_{2}$ is peak of the methylene in glycerol.

The biodiesel product from transesterification has been purified and used to study its properties using the following standard condition: acid value (ASTM D664), kinematic viscosity at $40^{\circ} \mathrm{C}$ (ASTM D445), density (ASTM D1298), and flash point (ASTM D93).

\section{Results and Discussions}

3.1. Characterization of the 3DOM Materials. The morphology of the synthesized PMMA templates revealed monodispersed PMMA spheres with face-centered cubic (FCC) arrangement [9] (Figure 1(a)). The average diameter was approximately $338 \pm 38 \mathrm{~nm}$. These PMMA colloidal crystals were used as templates for syntheses of $3 \mathrm{DOM} \mathrm{CaO} / \mathrm{SiO}_{2}$, $3 \mathrm{DOM} \mathrm{CaO} / \mathrm{Al}_{2} \mathrm{O}_{3}$, and $3 \mathrm{DOM} \mathrm{Ca}_{12} \mathrm{Al}_{14} \mathrm{O}_{32} \mathrm{Cl}_{2}$ catalysts for transesterification reaction.

The morphology of the $3 \mathrm{DOM} \mathrm{CaO} / \mathrm{SiO}_{2}$ calcined at 600,700 , and $800^{\circ} \mathrm{C}$ was exhibited in Figures $1(\mathrm{~b})-1(\mathrm{~d})$. It can be seen that a highly ordered porosity was achieved at the temperature of 600 and $700^{\circ} \mathrm{C}$ (Figures 1(b) and $1(\mathrm{c})$ ), 


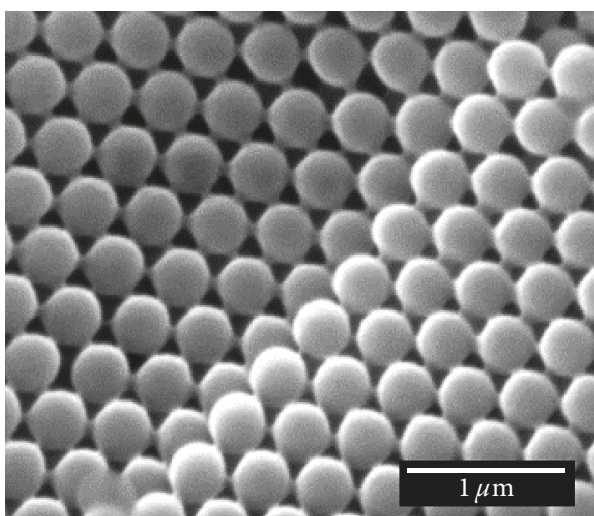

(a)

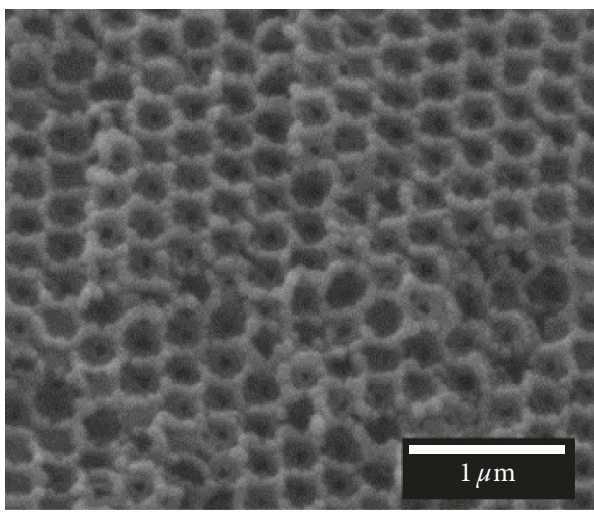

(c)

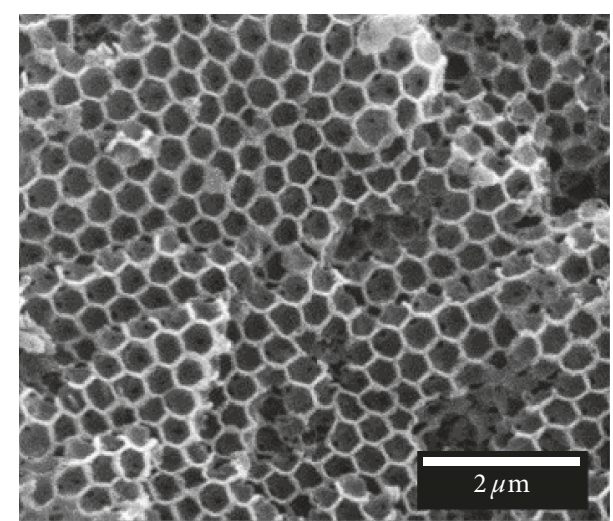

(b)

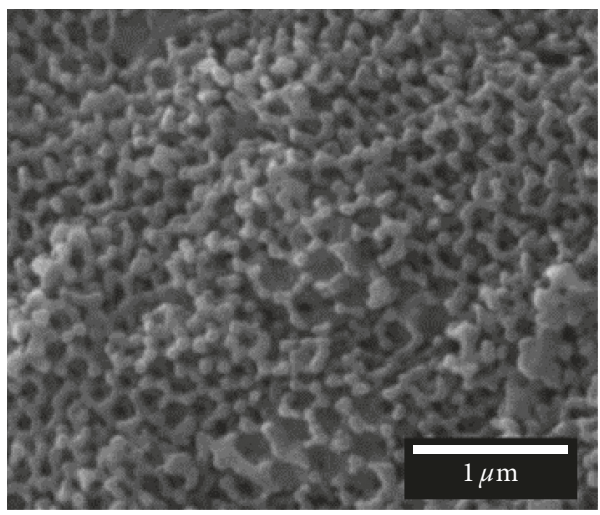

(d)

Figure 1: SEM images of (a) PMMA colloid crystals and (b-d) $3 \mathrm{DOM} \mathrm{CaO} / \mathrm{SiO}_{2}$ at 600,700 , and $800^{\circ} \mathrm{C}$, respectively.

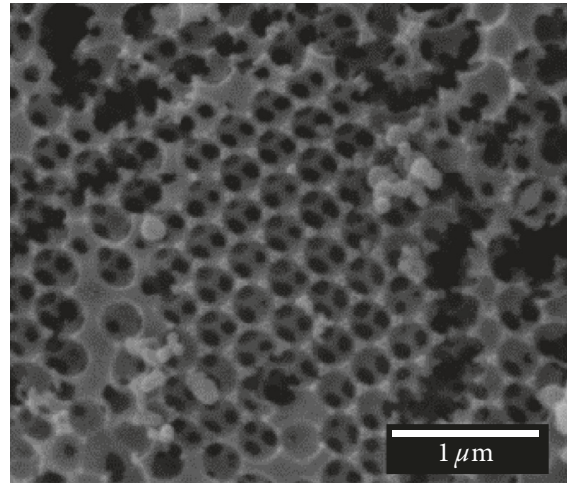

(a)

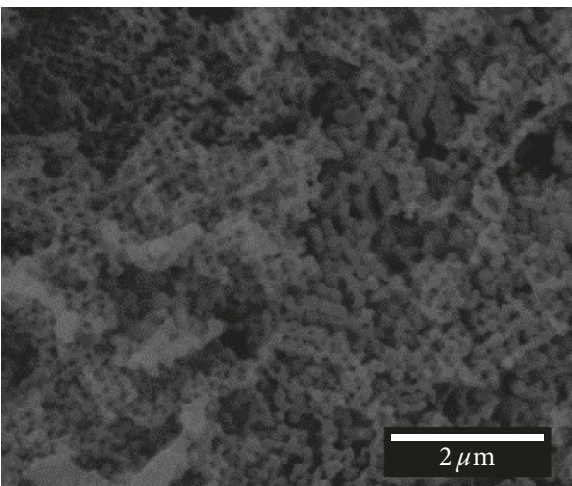

(b)

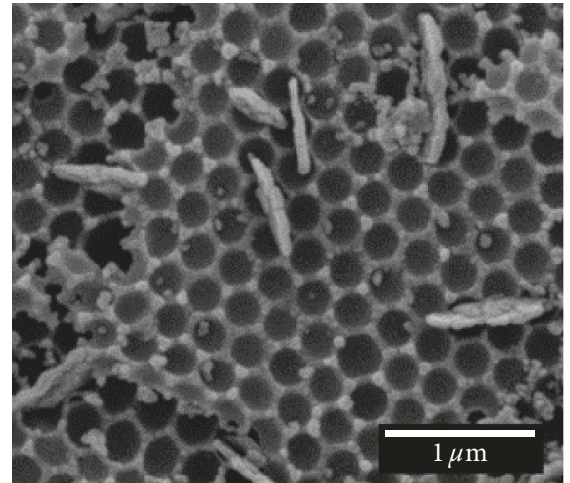

(c)

Figure 2: SEM images of $3 \mathrm{DOM} \mathrm{CaO} / \mathrm{Al}_{2} \mathrm{O}_{3}(\mathrm{a})$ at $700^{\circ} \mathrm{C}(\times 40000)$ and (b) at $800^{\circ} \mathrm{C}(\times 20000)$ and (c) $3 \mathrm{DOM} \mathrm{Ca}_{12} \mathrm{Al}_{14} \mathrm{O}_{32} \mathrm{Cl}_{2}$ at $700^{\circ} \mathrm{C}$ $(\times 40000)$.

respectively. However, the $3 \mathrm{DOM} \mathrm{CaO} / \mathrm{SiO}_{2}$ at $800^{\circ} \mathrm{C}$ was a nonordered structure due to high calcination temperature (Figure 1(d)). Increasing the calcination temperature may result in accumulation and sintering of $\mathrm{Ca}$, resulting in bigger particles and decreasing in surface area $[10,11]$.

The SEM images of the synthesized $3 \mathrm{DOM} \mathrm{CaO} / \mathrm{Al}_{2} \mathrm{O}_{3}$ at 700 and $800^{\circ} \mathrm{C}$ were shown in Figures 2(a) and 2(b). The 3DOM structures were obtained after calcination at $700^{\circ} \mathrm{C}$ with average porous diameter of $231 \pm 17 \mathrm{~nm}$. At $800^{\circ} \mathrm{C}$, the failures of the hierarchical structures of the $3 \mathrm{DOM} \mathrm{CaO} / \mathrm{Al}_{2} \mathrm{O}_{3}$ were similar to the $3 \mathrm{DOM} \mathrm{CaO} / \mathrm{SiO}_{2}$ at $800^{\circ} \mathrm{C}$. The morphology of $3 \mathrm{DOM}$ $\mathrm{Ca}_{12} \mathrm{Al}_{14} \mathrm{O}_{32} \mathrm{Cl}_{2}$ at $700^{\circ} \mathrm{C}$ was also achieved with a pore diameter of $165 \pm 9 \mathrm{~nm}$ with irregular particles on the surface (Figure 2(c)).

The XRD patterns of the $3 \mathrm{DOM} \mathrm{CaO} / \mathrm{SiO}_{2}$ catalysts at $600-800^{\circ} \mathrm{C}$ are shown in Figure 3. At $600^{\circ} \mathrm{C}$, an amorphous $\mathrm{SiO}_{2}$ band centered at $30^{\circ}$ and $\mathrm{CaCO}_{3}$ at $29^{\circ}$ (104) were 


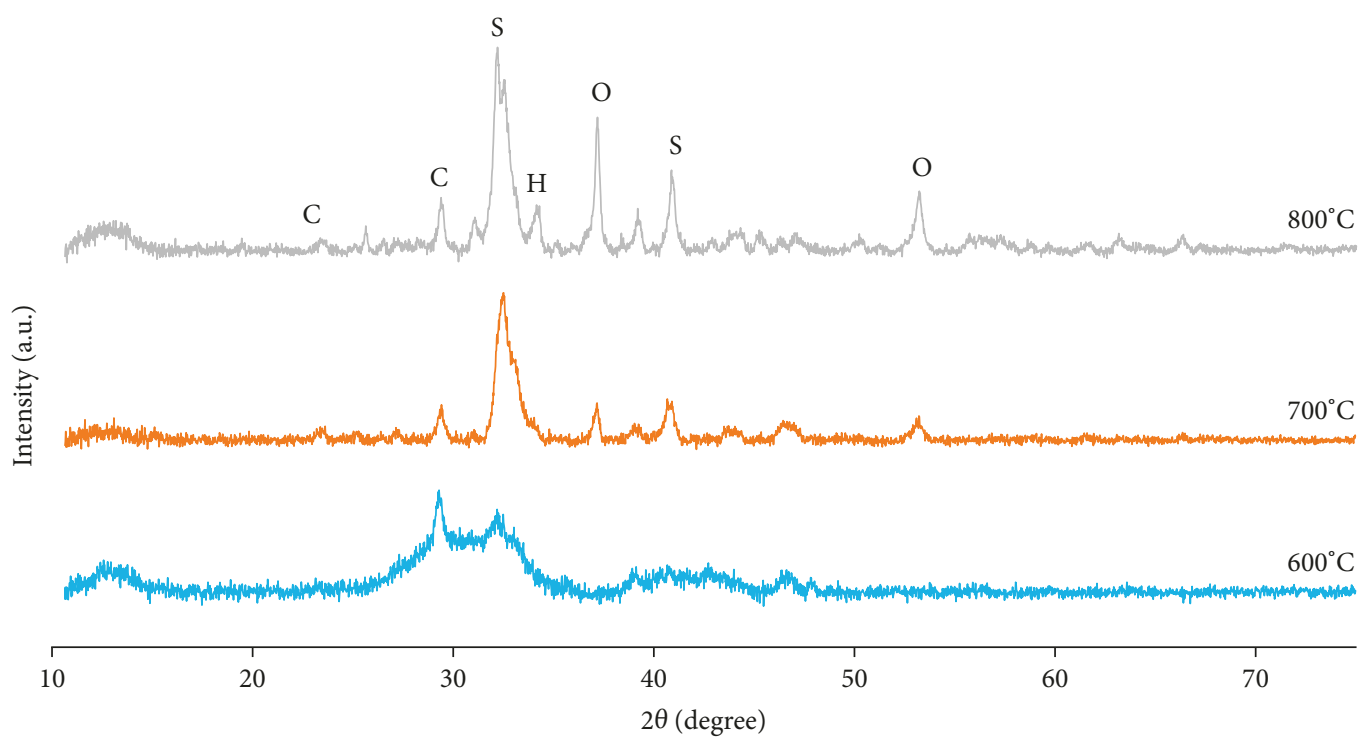

Figure 3: XRD patterns of the $3 \mathrm{DOM} \mathrm{CaO} / \mathrm{SiO}_{2} . \mathrm{H}=\mathrm{Ca}(\mathrm{OH})_{2}, \mathrm{O}=\mathrm{CaO}, \mathrm{S}=\mathrm{Ca}_{2} \mathrm{SiO}_{4}$, and $\mathrm{C}=\mathrm{CaCO}_{3}$.

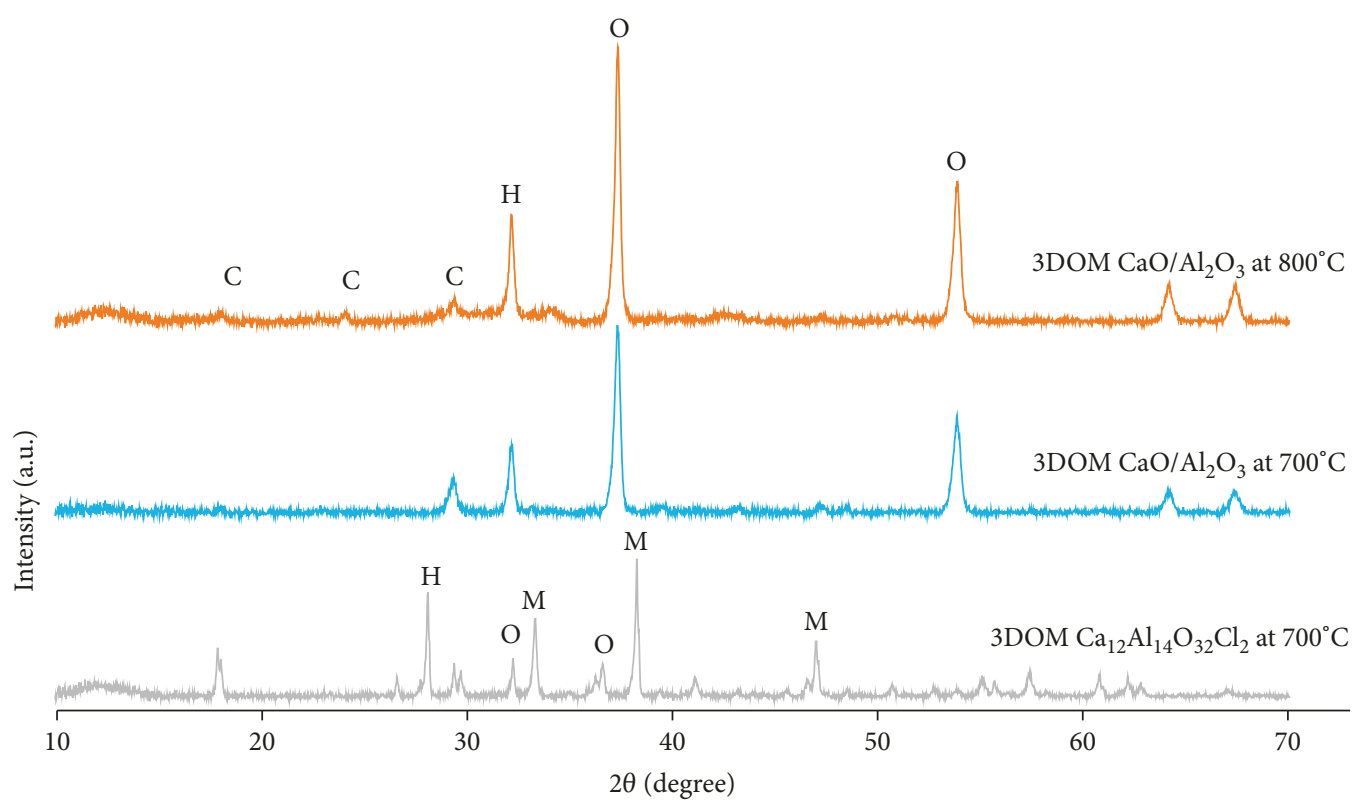

Figure 4: $\mathrm{XRD}$ patterns of the $3 \mathrm{DOM} \mathrm{CaO} / \mathrm{Al}_{2} \mathrm{O}_{3}$ at $700-800^{\circ} \mathrm{C}$ and the $3 \mathrm{DOM} \mathrm{Ca} \mathrm{Ca}_{12} \mathrm{Al}_{14} \mathrm{O}_{32} \mathrm{Cl}_{2} \cdot \mathrm{H}=\mathrm{Ca}(\mathrm{OH})_{2}, \mathrm{O}=\mathrm{CaO}, \mathrm{M}=\mathrm{Ca}_{12} \mathrm{Al}_{14} \mathrm{O}_{32} \mathrm{Cl}_{2}$, and $\mathrm{C}=\mathrm{CaCO}_{3}$.

presented. No calcium oxide was observed because a decomposition of $\mathrm{CaCO}_{3}$ to $\mathrm{CaO}$ occurs at temperature higher than $600^{\circ} \mathrm{C}[12]$. The diffraction peaks at $32^{\circ}(222), 41^{\circ}(081)$, and $44^{\circ}$ (281) corresponded to calcium silicate $\left(\mathrm{Ca}_{2} \mathrm{SiO}_{4}\right)$ (JPCDS 33-303) and $\mathrm{CaCO}_{3}$ at $23^{\circ}$ (012), $29^{\circ}$ (104), and $47^{\circ}$ (018) (JPCDS. 5-586) were observed after calcination at 700 and $800^{\circ} \mathrm{C}$. The $3 \mathrm{DOM} \mathrm{CaO} / \mathrm{SiO}_{2}$ at $800^{\circ} \mathrm{C}$ exhibited similar XRD patterns with $\mathrm{Ca}_{2} \mathrm{SiO}_{4}$ as a major phase and $\mathrm{CaO}$, $\mathrm{CaCO}_{3}$, and $\mathrm{Ca}(\mathrm{OH})_{2}$ as minor phases (Figure 3).

The XRD patterns of the $3 \mathrm{DOM} \mathrm{CaO} / \mathrm{Al}_{2} \mathrm{O}_{3}$ after calcination at 700 and $800^{\circ} \mathrm{C}$ are shown in Figure 4. Both samples exhibited diffraction peaks at $32^{\circ}(111), 37^{\circ}(200), 54^{\circ}(220), 64^{\circ}(311)$, and $67^{\circ}(222)$ corresponding to $\mathrm{CaO}$ and weak diffractions peaks of $\mathrm{Ca}(\mathrm{OH})_{2}$ and $\mathrm{CaCO}_{3}$. The XRD pattern of the $3 \mathrm{DOM}$ $\mathrm{Ca}_{12} \mathrm{Al}_{14} \mathrm{O}_{32} \mathrm{Cl}_{2}$ at $700^{\circ} \mathrm{C}$ exhibited mixed phase of $\mathrm{Cl}$-bearing mayenite (JCPDS 1-77-4045) [13] with $\mathrm{CaO}$ and $\mathrm{Ca}(\mathrm{OH})_{2}$.

The FTIR spectra of all $3 \mathrm{DOM} \mathrm{CaO} / \mathrm{SiO}_{2}$ exhibited characteristic bands at $1000 \mathrm{~cm}^{-1}$ and $480 \mathrm{~cm}^{-1}$, corresponding to stretching and bending vibration of $\mathrm{Si}-\mathrm{O}$ bond, respectively [14] (Figure 5). The band at approximately $3600 \mathrm{~cm}^{-1}$ was associated with the $\mathrm{OH}$ stretching vibrations of surface hydroxyl groups $(\mathrm{Ca}-\mathrm{OH})$ due to moisture absorption [15]. The band at $1460 \mathrm{~cm}^{-1}$ was a $\mathrm{C}=\mathrm{O}$ vibration of the carbonate group. It is noted that different calcination temperatures did not significantly alter the FTIR pattern of the $3 \mathrm{DOM} \mathrm{CaO} / \mathrm{SiO}_{2}$. FTIR spectra of both $3 \mathrm{DOM} \mathrm{CaO} / \mathrm{Al}_{2} \mathrm{O}_{3}$ and $3 \mathrm{DOM}$ 


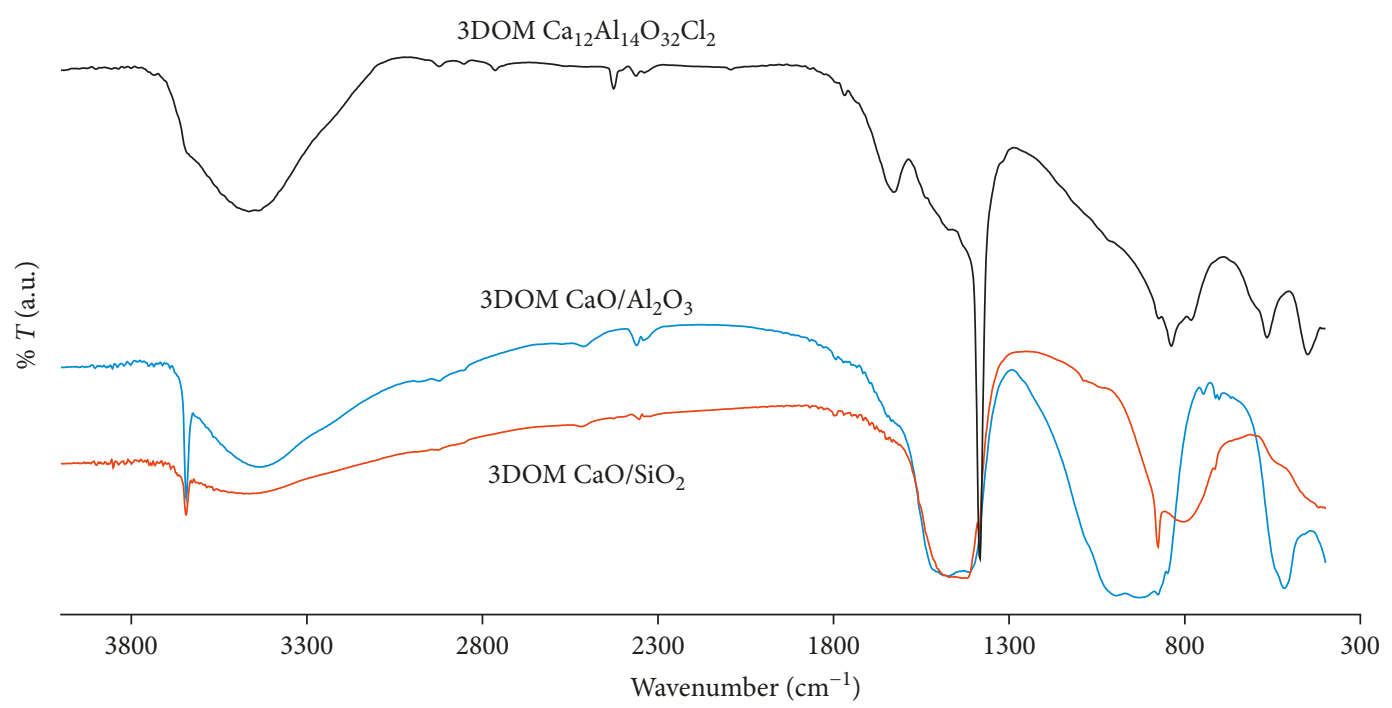

Figure 5: FTIR spectra of the $3 \mathrm{DOM} \mathrm{CaO} / \mathrm{Al}_{2} \mathrm{O}_{3}$ at $700-800^{\circ} \mathrm{C}$ and the $3 \mathrm{DOM} \mathrm{Ca}{ }_{12} \mathrm{Al}_{14} \mathrm{O}_{32} \mathrm{Cl}_{2}$.

$\mathrm{Ca}_{12} \mathrm{Al}_{14} \mathrm{O}_{32} \mathrm{Cl}_{2}$ exhibited characteristic bands at $500-700 \mathrm{~cm}^{-1}$ and $700-900 \mathrm{~cm}^{-1}$ which corresponded to $\mathrm{Al}-\mathrm{O}$ vibration of octahedral and tetrahedral $\mathrm{Al}_{2} \mathrm{O}_{3}$, respectively [3]. The strong board band centered at $1460 \mathrm{~cm}^{-1}$ was attributed to $\mathrm{C}=\mathrm{O}$ vibration of the carbonate group. The band at $3645 \mathrm{~cm}^{-1}$ indicated $\mathrm{OH}$ stretching vibration of the absorbed water molecules onto $\mathrm{CaO}$ giving rise to $\mathrm{Ca}(\mathrm{OH})_{2}[16]$.

3.2. Transesterification. Numerous 3DOM catalysts were prepared. However, not all 3DOM catalysts were suitable for transesterification; for example, the 3DOM $\mathrm{CaO} / \mathrm{SiO}_{2}$ calcined at $600^{\circ} \mathrm{C}$ was achieved but no active $\mathrm{CaO}$ was found. At $700-800^{\circ} \mathrm{C}, \mathrm{CaO}$ was produced in the $3 \mathrm{DOM} \mathrm{CaO} / \mathrm{SiO}_{2}$, but preliminary transesterification studied showed no RPO conversion. Therefore, all $3 \mathrm{DOM} \mathrm{CaO} / \mathrm{SiO}_{2}$ catalyst were not used for transesterification.

Both 3DOM CaO/ $\mathrm{Al}_{2} \mathrm{O}_{3}$ and $3 \mathrm{DOM} \mathrm{Ca}_{12} \mathrm{Al}_{14} \mathrm{O}_{32} \mathrm{Cl}_{2}$ were used as a solid catalyst for transesterification of palm oil with methanol at $65^{\circ} \mathrm{C}$ and stirring rate at $750 \mathrm{rpm}$. The basicity of the catalysts was previously studied using the Hammett indicator [16-18]. The basicity of $3 \mathrm{DOM} \mathrm{CaO} / \mathrm{Al}_{2} \mathrm{O}_{3}$ was in the range of $10.0<\mathrm{H}_{-}<12.2$, whereas that of 3DOM $\mathrm{Ca}_{12} \mathrm{Al}_{14} \mathrm{O}_{32} \mathrm{Cl}_{2}$ is $11<\mathrm{H}_{-}<15$.

For $3 \mathrm{DOM} \mathrm{CaO} / \mathrm{Al}_{2} \mathrm{O}_{3}$, the effect of catalyst amount was investigated ranging from 6 to $12 \mathrm{wt}$.\% with molar ratio of methanol to oil of $12: 1$ at $65^{\circ} \mathrm{C}$ for $3 \mathrm{~h}$. It was found that the refined palm oil (RPO) conversion increased with the increase of the catalyst amount (Figure 6(a)). The $12 \mathrm{wt} . \%$ of catalyst gave the highest RPO conversion of 58\%. Although the stoichiometric ratio of methanol to palm oil for transesterification is $3: 1$, additional of methanol makes equilibrium moving forward to produce more biodiesel. In this study, it was found that the reaction using $3 \mathrm{DOM}$ $\mathrm{CaO} / \mathrm{Al}_{2} \mathrm{O}_{3}$ catalyst at $12: 1 \mathrm{MeOH}$ : oil ratio resulted in $47 \%$ RPO conversion. However, the higher $\mathrm{MeOH}$ : oil ratio at $18: 1$ and $24: 1$ only produced $40 \%$ and $17 \%$ RPO conversion, respectively (Figure 6(b)). The decreasing of RPO conversion may be due to an alternation of the reaction equilibrium. Excess methanol may increase the solubility of glycerol; therefore, the equilibrium of the reaction shifted backward, resulting in a reduction of biodiesel $[16,19]$. The effect of reaction time is shown in Figure 6(c). The reaction time of 3 h gave the lowest RPO conversion of $47 \%$ because reaction was incomplete. When the reaction time was increased, the RPO conversion increased to the highest value of $94 \%$ at $5 \mathrm{~h}$. The optimal conditions using the $3 \mathrm{DOM} \mathrm{CaO} / \mathrm{Al}_{2} \mathrm{O}_{3}$ catalyst were as follows: $12 \mathrm{wt} \%$ catalyst, methanol to oil molar ratio of $12: 1$, and reaction time $5 \mathrm{~h}$ under the temperature of $65^{\circ} \mathrm{C}$.

For the $3 \mathrm{DOM} \mathrm{Ca}_{12} \mathrm{Al}_{14} \mathrm{O}_{32} \mathrm{Cl}_{2}$ catalyst, the effects of the catalyst amounts varied from 3 to $12 \mathrm{wt} . \%$. It can be seen that increasing catalyst amount gives higher RPO conversion (Figure 6(a)). However, a high catalyst amount (12 wt.\%) was not suitable for transesterification because the high catalyst amount led to high viscosity in mixture. The optimum catalyst amount is $6 \mathrm{wt} . \%$ by weight. At $\mathrm{MeOH}$ : oil molar ratio of $9: 1$, the RPO conversion of $96 \%$ was observed (Figure 6(b)). The increasing methanol to oil molar ratio of $12: 1$ and $18: 1$ gave the maximum highest RPO conversion of $99 \%$. The effects of reaction time are shown in Figure 6(c). It obtained the highest RPO conversion at $3 \mathrm{~h}$. The optimal conditions for transesterification were obtained as follows: by the catalyst amount $6 \mathrm{wt} . \%$, methanol to oil molar ratio $12: 1$, and reaction time of $3 \mathrm{~h}$. The RPO conversion was obtained at $99 \%$ under the optimal condition.

3.3. Biodiesel Properties. The properties of biodiesel obtained from transesterification using $3 \mathrm{DOM} \mathrm{CaO} / \mathrm{Al}_{2} \mathrm{O}_{3}$ and $3 \mathrm{DOM}$ $\mathrm{Ca}_{12} \mathrm{Al}_{14} \mathrm{O}_{32} \mathrm{Cl}_{2}$ were studied following the biodiesel standard of USA (ASTM) and Europe (EN) as shown in Table 2. The density of the produced biodiesel was acceptable, but the acid value and viscosity did not meet the standard value. This may be due to the high acid value (3.02) of raw material. Therefore, the raw material should be esterified to reduce free fatty acid 


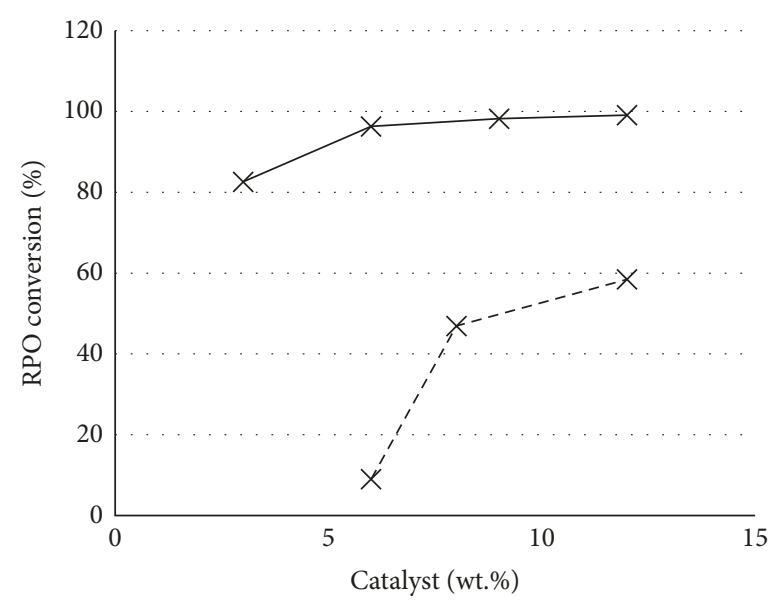

(a)

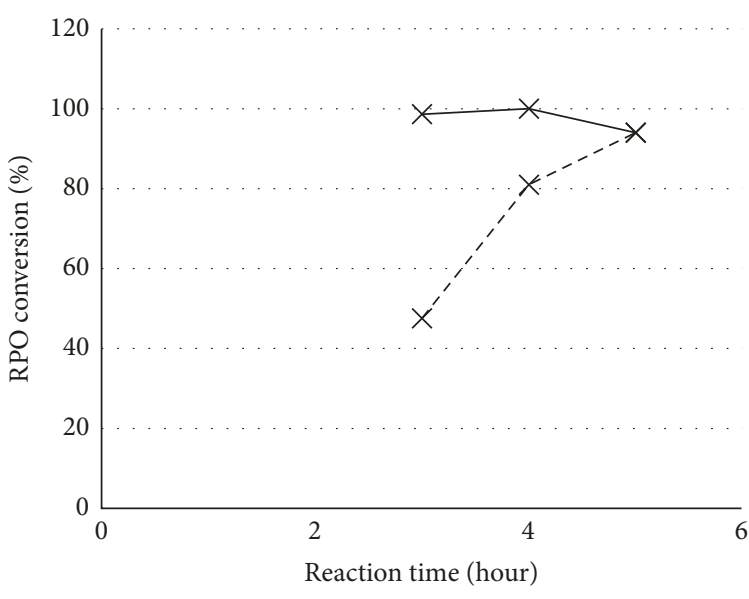

(b)

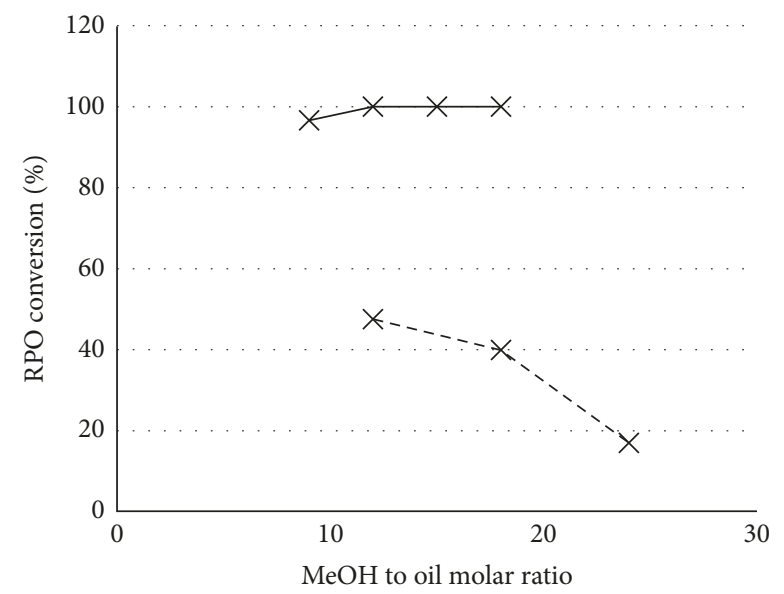

(c)

FIgURE 6: RPO conversion: (a) effect of \% wt. catalyst, (b) effect of $\mathrm{MeOH}$ : oil molar ratio, and (c) effect of reaction time.

TABLE 2: Properties of RPO biodiesel.

\begin{tabular}{lccc}
\hline Parameters & Testing method (standard value) & Limitation of Thai community & Biodiesel in this study \\
\hline Viscosity at $40^{\circ} \mathrm{C}(\mathrm{cSt})$ & ASTM D445 $(1.9-6.0)$ & $1.9-6.0$ & 7.1 \\
Density at $15^{\circ} \mathrm{C}\left(\mathrm{g} / \mathrm{cm}^{3}\right)$ & EN 14214 $(0.86-0.90)$ & $0.86-0.90$ & 0.86 \\
Acid value $(\mathrm{mg} \mathrm{KOH} / \mathrm{g})$ & ASTM D664 $(0.50 \mathrm{max})$ & $0.80 \mathrm{max}$ & 1.64 \\
\hline
\end{tabular}

[7]. The high viscosity may be due to the Ca contaminant which causes side reaction (saponification) producing soap which then increases the viscosity of the biodiesel.

\section{Conclusion}

The $3 \mathrm{DOM} \mathrm{CaO} / \mathrm{SiO}_{2}, 3 \mathrm{DOM} \mathrm{CaO} / \mathrm{Al}_{2} \mathrm{O}_{3}$, and $3 \mathrm{DOM}$ $\mathrm{Ca}_{12} \mathrm{Al}_{14} \mathrm{O}_{32} \mathrm{Cl}_{2}$ were successfully fabricated. The $3 \mathrm{DOM}$ $\mathrm{CaO} / \mathrm{SiO}_{2}$ catalysts calcined at $700^{\circ} \mathrm{C}$ obtained the crystalline phase of $\mathrm{CaCO}_{3}, \mathrm{Ca}(\mathrm{OH})_{2}, \mathrm{CaO}$, and $\mathrm{Ca}_{2} \mathrm{SiO}_{4}$. The $3 \mathrm{DOM}$ $\mathrm{CaO} / \mathrm{Al}_{2} \mathrm{O}_{3}$ catalysts calcined at 700 and $800^{\circ} \mathrm{C}$ obtained crystalline of $\mathrm{CaO}$ and $\mathrm{Ca}(\mathrm{OH})_{2}$. The results of FTIR spectra were corresponded with functional groups of silica $\left(\mathrm{SiO}_{2}\right)$, alumina $\left(\mathrm{Al}_{2} \mathrm{O}_{3}\right)$, carbonate $\left(\mathrm{CO}_{3}^{2-}\right)$, and hydroxyl $\left(\mathrm{OH}^{-}\right)$groups, depending on the composition of the 3DOM materials. The $3 \mathrm{DOM} \mathrm{CaO} / \mathrm{SiO}_{2}$ was not suitable for the reaction due to no active $\mathrm{CaO}$. In addition, 3DOM materials that calcined at $800^{\circ} \mathrm{C}$ exhibited collapsed 3DOM structure. Only 3DOM CaO/ $\mathrm{Al}_{2} \mathrm{O}_{3}$ and $\mathrm{Ca}_{12} \mathrm{Al}_{14} \mathrm{O}_{32} \mathrm{Cl}_{2}$ were used for transesterification, because the ordered structure of both catalysts was maintained with an active $\mathrm{CaO}$ phase after calcination.

For $3 \mathrm{DOM} \mathrm{CaO} / \mathrm{Al}_{2} \mathrm{O}_{3}$, the optimal condition was $12 \mathrm{wt}$. $\%$ of catalyst, the methanol to oil molar ratio of $12: 1$, and reaction time of $5 \mathrm{~h}$ under stirring rate of $750 \mathrm{rpm}$ and reaction temperature at $65^{\circ} \mathrm{C}$, giving rise to $93 \%$ of $\mathrm{RPO}$ conversion. The optimal condition of the novel 3DOM $\mathrm{Ca}_{12} \mathrm{Al}_{14} \mathrm{O}_{32} \mathrm{Cl}_{2}$ catalyst was as follows: the catalyst amount $6 \mathrm{wt} . \%$, the methanol to oil molar ratio of $12: 1$, and reaction time of $3 \mathrm{~h}$ under stirring rate of $750 \mathrm{rpm}$ and reaction 
temperature at $65^{\circ} \mathrm{C}$, giving $99 \%$ of $\mathrm{RPO}$ conversion. The 3DOM $\mathrm{Ca}_{12} \mathrm{Al}_{14} \mathrm{O}_{32} \mathrm{Cl}_{2}$ catalyst had more efficiency than conventional solid and $3 \mathrm{DOM} \mathrm{CaO} / \mathrm{Al}_{2} \mathrm{O}_{3}$ catalysts. The density of biodiesel was $0.86 \mathrm{~g} / \mathrm{cm}^{3}$ which was in the ASTM specification. The viscosity and acid value of biodiesel product were slightly out of standard range (ASTM D445 and ASTM D664, resp.). This may be due to the Ca contaminant causing saponification. The density of biodiesel, however, was within specification (EN 14214).

\section{Conflicts of Interest}

The authors declare that they have no conflicts of interest.

\section{Acknowledgments}

The authors would like to thank the Kasetsart University Research and Development Institute (KURDI) and Faculty of Science, Kasetsart University, for financial supports. The authors also express gratitude to the Center of ExcellenceOil Palm, Kasetsart University, for instrumental assistance.

\section{References}

[1] A. Srivastava and R. Prasad, "Triglycerides-based diesel fuels," Renewable and Sustainable Energy Reviews, vol. 4, no. 2, pp. 111-133, 2000.

[2] S. Al-Zuhair, "Production of biodiesel: possibilities and challenges," Biofuels, Bioproducts and Biorefining, vol. 1, no. 1, pp. 57-66, 2007.

[3] I. Lukić, J. Krstić, D. Jovanović, and D. Skalaa, “Alumina/silica supported $\mathrm{K}_{2} \mathrm{CO}_{3}$ as a catalyst for biodiesel synthesis from sunflower oil," Bioresource Technology, vol. 100, no. 20, pp. 4690-4696, 2009.

[4] H. Sun, Y. Ding, J. Duan et al., "Transesterification of sunflower oil to biodiesel on $\mathrm{ZrO}_{2}$ supported $\mathrm{La}_{2} \mathrm{O}_{3}$ catalyst," Bioresource Technology, vol. 101, no. 3, pp. 953-958, 2010.

[5] A. P. Vyas, N. Subrahmanyam, and P. A. Patel, "Production of biodiesel through transesterification of Jatropha oil using $\mathrm{KNO}_{3} / \mathrm{Al}_{2} \mathrm{O}_{3}$ solid catalyst," Fuel, vol. 88 , no. 4, pp. 625-628, 2009.

[6] N. Phumthiean, Development and Characterization of ThreeDimensionally Ordered Macroporous Hydroxyapatite (3DOM HAp) by Sol-Gel Technique and Its Application as Vancomycin Drug Carrier, Department of Chemistry, Kasetsart University, Bangkok, Thailand, 2013.

[7] W. Suwanthai, Optimization of Refined Bleached and deodorized Palm Oil Biodiesel Production Using Calcium Methoxide Catalyst by Response Surface Methodology, Department of Chemistry, Kasetsart University, Bangkok, Thailand, 2014.

[8] M. Tariq, S. Ali, F. Ahmad et al., "Identification, FT-IR, NMR $\left({ }^{1} \mathrm{H}\right.$ and $\left.{ }^{13} \mathrm{C}\right)$ and GC/MS studies of fatty acid methyl esters in biodiesel from rocket seed oil," Fuel Processing Technology, vol. 92, no. 3, pp. 336-341, 2011.

[9] P. N. Pusey and W. van Megen, "Phase behaviour of concentrated suspensions of nearly hard colloidal spheres," Nature, vol. 320, no. 6060, pp. 340-342, 1986.

[10] R.-X. Yang, K.-H. Chuang, and M.-Y. Wey, "Hydrogen production through methanol steam reforming: effect of synthesis parameters on $\mathrm{Ni}-\mathrm{Cu} / \mathrm{CaO}-\mathrm{SiO}_{2}$ catalysts activity," International Journal of Hydrogen Energy, vol. 39, no. 34, pp. 19494-19501, 2014.
[11] X. Zhang, H. Su, and X. Yang, "Catalytic performance of a three-dimensionally ordered macroporous $\mathrm{Co} / \mathrm{ZrO}_{2}$ catalyst in Fischer-Tropsch synthesis," Journal of Molecular Catalysis A: Chemical, vol. 360, pp. 16-25, 2012.

[12] M. L. Granados, M. D. Zafra Poves, D. MartínAlonso et al., "Biodiesel from sunflower oil by using activated calcium oxide," Applied Catalysis B: Environmental, vol. 73, no. 3-4, pp. 317-326, 2007.

[13] C. Ma, H. C. Connolly, J. R. Beckett et al., "Brearleyite, $\mathrm{Ca}_{12} \mathrm{Al}_{14} \mathrm{O}_{32} \mathrm{Cl}_{2}$, a new alteration mineral from the NWA 1934 meteorite," American Mineralogist, vol. 96, no. 8-9, pp. 1199-1206, 2011.

[14] H. Yan, K. Zhang, C. F. Blanford, L. F. Francis, and A. Stein, "In vitro hydroxycarbonate apatite mineralization of $\mathrm{CaO}-\mathrm{SiO}_{2}$ sol-gel glasses with a three-dimensionally ordered macroporous structure," Chemistry of Materials, vol. 13, no. 4, pp. 1374-1382, 2001.

[15] B. Wang, S. Li, S. Tian, R. Feng, and Y. Meng, "A new solid base catalyst for the transesterification of rapeseed oil to biodiesel with methanol," Fuel, vol. 104, pp. 698-703, 2013.

[16] N. Pasupulety, K. Gunda, Y. Liu, G. L. Rempel, and F. T. T. Ng, "Production of biodiesel from soybean oil on $\mathrm{CaO} / \mathrm{Al}_{2} \mathrm{O}_{3}$ solid base catalysts," Applied Catalysis A: General, vol. 452, pp. 189-202, 2013.

[17] S. Sankaranarayanan, C. A. Antonyraj, and S. Kannan, "Transesterification of edible, non-edible and used cooking oils for biodiesel production using calcined layered double hydroxides as reusable base catalysts," Bioresource Technology, vol. 109, pp. 57-62, 2012.

[18] G. Joshi, D. S. Rawat, B. Y. Lamba et al., "Transesterification of Jatropha and Karanja oils by using waste egg shell derived calcium based mixed metal oxides," Energy Conversion and Management, vol. 96, pp. 258-267, 2015.

[19] G.-Y. Chen, R. Shan, J. F. Shi, and B. B. Yan, "Transesterification of palm oil to biodiesel using rice husk ash-based catalysts," Fuel Processing Technology, vol. 133, pp. 8-13, 2015. 


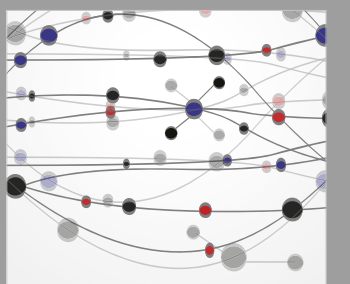

The Scientific World Journal
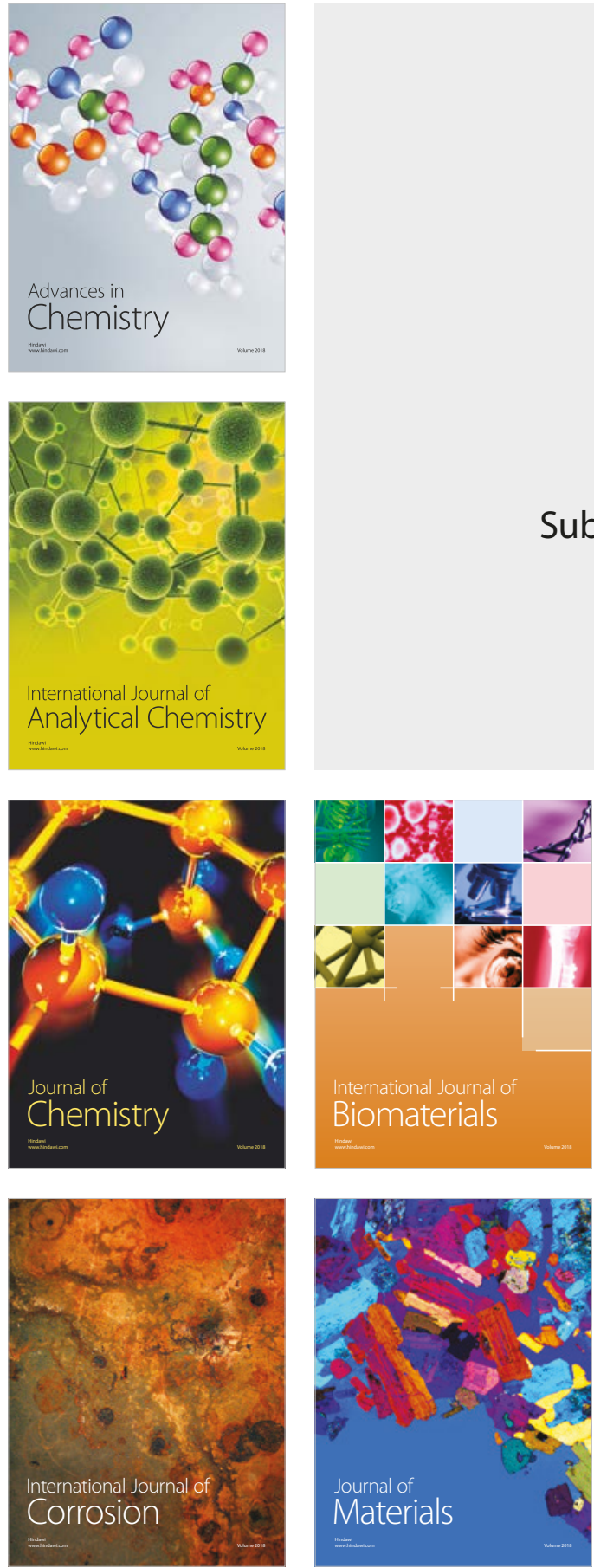

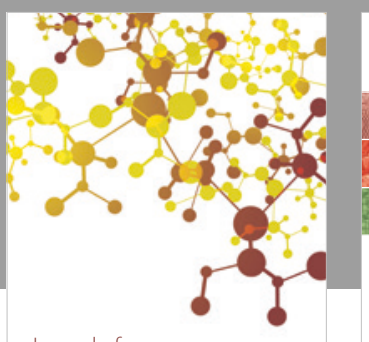

Journal of

Applied Chemistry
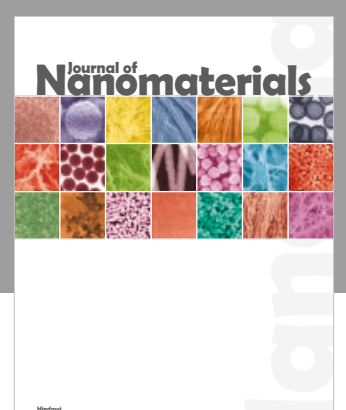

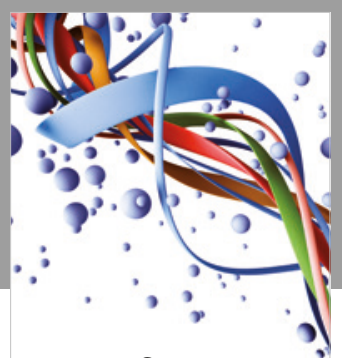

Scientifica

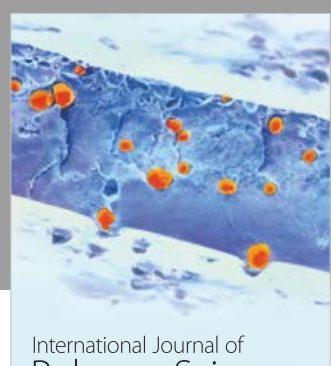

Polymer Science

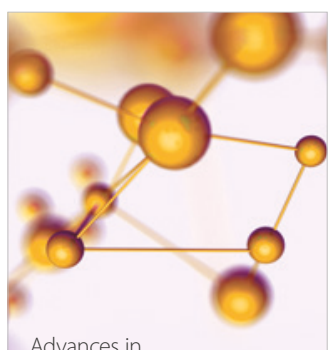

Physical Chemistry
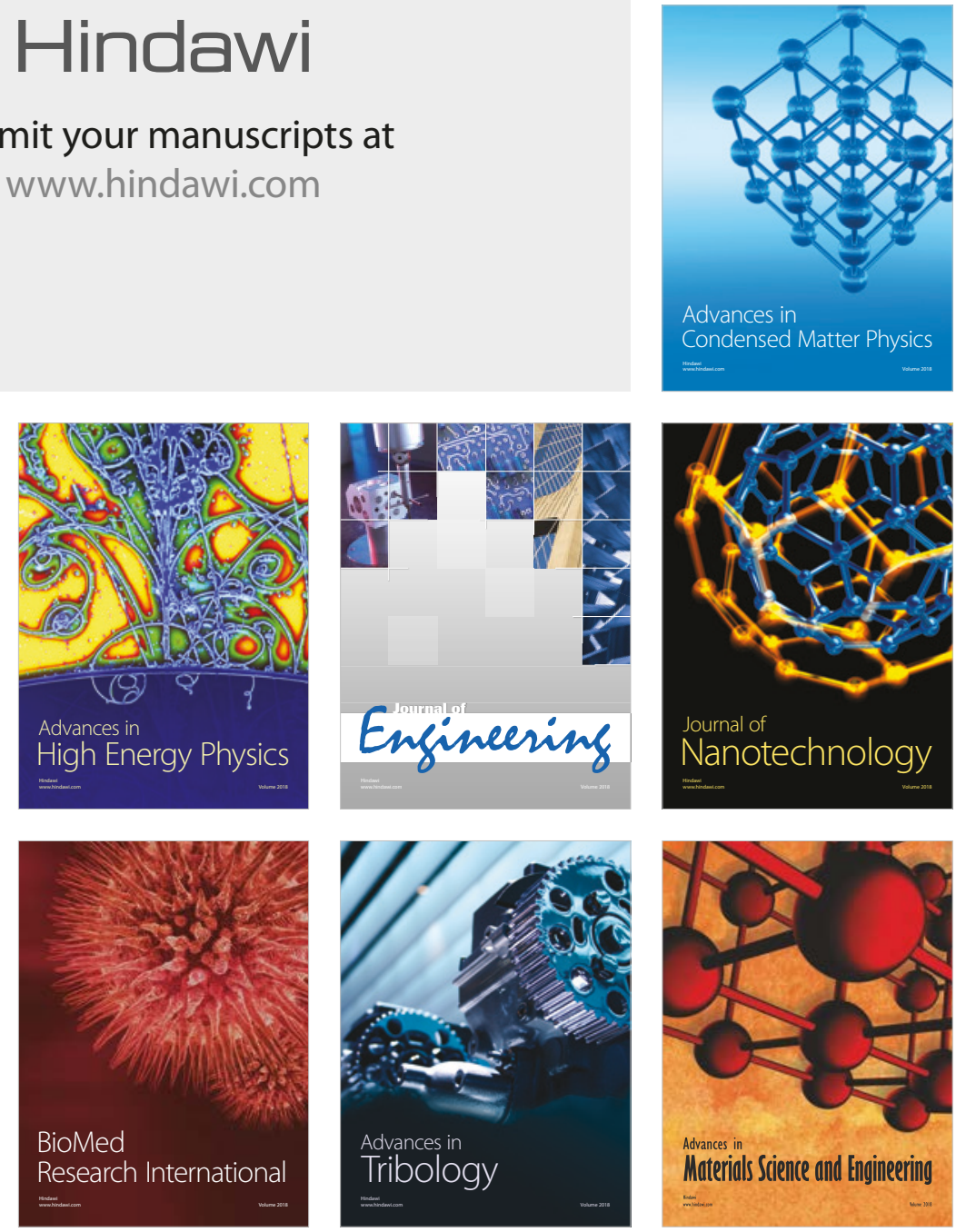